\title{
ETHICAL STANDARDS FOR THE OCCUPATIONAL HEALTH-NURSING PRACTITIONER REGARDING THE HIV POSITIVE PERSON IN THE WORKPLACE
}

\section{Otto}

Master student, Department of Nursing Science

Rand Afrikaans University

AC Botes

Professor, Department of Nursing Science

Rand Afrikaans University

\begin{abstract}
The occupational health-nursing practitioner often becomes involved in ethical dilemmas with regard to the handling of HIV-positive people in the workplace in that the interests of the HIV-positive people conflict with the interests of the employer. Therefore, the occupational health-nursing practitioner could find himself/ herself acting as mediator between the two parties. Despite the existence of legal norms and ethical standards to regulate the interests of the HIV-positive person in the workplace, no guidelines exist as to how these norms and standards should be operationalised during interaction between the HIV-positive person, the occupational health-nursing practitioner and the employer. The occupational health-nursing practitioner is therefore uncertain as to the manner in which to act professionally within the laid-down ethical standards for HIVpositive people in the workplace.
\end{abstract}

The purpose of this study is to provide guidelines and criteria for the operationalisation of ethical standards for the occupational health-nursing practitioner regarding the HIV-positive person in the workplace. This is done through a literature study with specific reference to current ethical frameworks within the occupational health context, after which the research is focused on two target groups, namely the occupational healthnursing practitioners and HIV-positive persons in the workplace. The design of the research is qualitative, explorative and descriptive. In order to assist the occupational health-nursing practitioner to handle the HIVpositive person in the workplace in an ethical manner, guidelines and criteria were compiled for the operationalisation of the standards.

\section{OPSOMMING}

Die beroepsgesondheidsverpleegkundige raak dikwels in etiese dilemmas betrokke ten opsigte van die hantering van die MIV-positiewe persoon by die werkplek deurdat die belange van die MIV-positiewe persoon botsend is met die belange van die werkgewer. Die beroepsgesondheidsverpleegkundige bevind hom/haar as tussenganger en advokaat tussen die twee partye, naamlik die werkgewer en die MIV-positiewe persoon. Ten spyte van die voorsiening van wetlike norme en etiese standaarde om die belange van die MIV-positiewe persoon by die werkplek te reguleer, bestaan daar geen praktykriglyne oor hoe hierdie wetlike norme en etiese standaarde geoperasionaliseer moet word tydens die interaksie tussen die MIV-positiewe persoon, die beroepsgesondheidsverpleegkundige en die werkgewer nie. Dit skep onsekerheid oor hoe hy/sy as professionele persoon vanuit die gestelde etiese standaarde teenoor die MIV-positiewe persoon by die werkplek behoort op te tree.

Hierdie studie het ten doel om riglyne en kriteria vir die operasionalisering van etiese standaarde vir die 
beroepsgesondheidsverpleegkundige oor die MIV-positiewe persoon by die werkplek te beskryf deur eerstens die literatuur te verken en te beskryf met spesifieke verwysing na die huidige wetlike en etiese raamwerke van die beroepsgesondheidskonteks, en tweedens die verkenning en beskrywing van probleme en oplossings van die twee teikengroepe, naamlik die beroepsgesondheidsverpleegkundiges en die MIV-positiewe persoon by die werkplek. Die navorsingsontwerp is kwalitatief, verkennend en beskrywend. Ten einde die beroepsgesondheidsverpleegkundige te help om die MIV-positiewe persoon by die werkplek eties te hanteer, is riglyne en kriteria vir die operasionalisering van die etiese standaarde opgestel.

\section{BACKGROUND, RATIONALE AND PROBLEM STATEMENT}

Since 1982 when the first person was diagnosed as being HIV-positive in South Africa, major changes in the relevant labour legislation, economy of businesses and health services delivery in the workplace have resulted. Employers set different criteria for new employees, resulting in the introduction of several discriminating practices, for instance the rejection of HIV-positive applicants, unfair dismissal of employees diagnosed as being HIV-positive as well as labelling and ill-treating of HIV-positive employees. It is to be recognised that the prevalence of HIV in young employees can have a serious impact on productivity of the individual and the economy as a whole. Such people can successfully contribute to the economy for many years before they develop full-blown AIDS, which will result in them becoming incapacitated. Discriminatory practices were therefore prevented by new concept legislation aimed at protecting the HIV-positive employee against unfair testing for the HI-virus, unfair dismissal and the segregation of HIV-positive prisoners (WHO, 2000:6-30; Arendse, 1988:218-219).

There are at present sufficient ethical standards and legal norms available to regulate the handling of, and interaction with, HIV-positive persons in the workplace. Examples of such legal norms are the Labour Relations Act, No 66 of 1995 and The Bill of Rights, as entrenched in The Constitution of the Republic of South Africa, No 108 of 1996.

Medical and nursing ethics deal with issues regarding professional behaviour that is of great importance to nurses and other health care providers. It primarily deals with morality, moral problems and moral judgements. In its most basic form, ethics has to do with the interpretation of words like "right", "wrong", "good", "bad", "ought to" and "obligation" (Deloughery, 1995:178-179). It implies that occupational health-nursing practitioners have to comply with ethical standards in every possible action and interaction in the workplace. Ethical standards are representative of the minimum requirements for ethical behaviour that are setting benchmarks for measuring compliance with ethical behaviour in a particular profession. It refers to the expected standard and behaviour as described in the professional code of behaviour for a specific group (Pera \& Van Tonder, 1996:4). While ethics deal with correct and expected behaviour amongst people of a certain profession, the legislation of a country is designed to regulate the behaviour of people on a larger scale, ensuring that law and order is maintained without anybody being placed above that law.

Occupational health-nursing practitioners are confronted daily with ethical questions and the lack of operational guidelines expose these practitioners to medico-legal accountability. "Good" and "other" as two central concepts in ethics mean that a person acts ethically when he/she acts in his/her own interest, whilst taking care of the interests of other people. An ethical dilemma is created, however, when there is conflict of interests between parties or persons. An ethical dilemma involving the HIVpositive person is created at the workplace in a situation where the interests of the HIV-positive person are in conflict with the interests of the employer. The occupational health-nursing practitioner finds himself/herself acting as a mediator 
between the two parties, namely the employer and the HIV-positive person. Despite the existence of legal norms and ethical standards to regulate the interests of the HIV-positive person in the workplace, no guidelines exist as to how these norms and standards should be operationalised during interaction between the HIV-positive person, the occupational health-nursing practitioner and the employer. The occupational health-nursing practitioners can therefore ask themselves, as professional people, how to handle the HIV-positive person in the workplace according to a set of ethical standards.

\section{PURPOSE AND OBJECTIVES}

The purpose of this study is to describe guidelines and criteria for the operationalisation of ethical standards for the occupational health nurse regarding the HIV-positive person in the workplace. This primary objective is achieved through the following secondary objectives:

- Exploring and describing literature with specific reference to current legal and ethical frameworks within the occupational health context regarding interaction with the HIVpositive person in the workplace in order to formulate the required ethical standards.

- Exploring and describing problems and solutions for the following target groups regarding the ethical aspects regarding the HIV-positive person in the workplace:

- Occupational health-nursing practitioners

- The HIV-positive person in the workplace.

\section{DEFINITION OF CONCEPTS}

\section{Ethical standards}

The minimum requirements against which ethical behaviour is measured to determine if there is compliance with the rules of a particular profession.

\section{Occupational health-nursing practitioner}

A nurse registered with the South African Nursing Council in General Nursing Science in terms of
Regulation 879, as amended. This nurse is also in possession of a post-basic certificate/diploma in Occupational Health, registered as an additional qualification with the South African Nursing Council (Act No. 50 of 1978).

\section{Workplace}

The nurse renders primary healthcare and occupational health service to the business sector. The workplace refers to the place where people are practising their occupations (Odendal \& Schoonees, 1991:1358). For the purpose of this study "workplace" refers to the factory where the employees and occupational health-nursing practitioner render a service for remuneration.

\section{HIV-positive persons}

Human Immune Deficiency Virus refers to the condition when antibodies against the HI-virus are present in the blood of a human. This virus penetrates the body and establishes itself in the human body affecting as many organs and human tissue as possible. The HIV-positive status is caused by a retrovirus that changes the genetic information in cells from RNA to DNA (Scoub, 1994:31-36).

\section{research DESIGN and methods}

A qualitative, explorative and descriptive design was used (Polit and Hungler, 1997:21). The research aimed at describing ethical guidelines and criteria for the operationalisation of ethical standards for the occupational health-nursing practitioner, insofar as the HIV-positive person in the workplace is concerned, was conducted in two phases.

During Phase 1 or the conceptual phase, the literature was researched with particular reference to current legal and ethical frameworks within the occupational health context, dealing with the interaction with the HIV-positive person in the workplace for the formulation of ethical standards.

- Phase 2, or the fieldwork, was conducted in 
two stages:

- During Stage 1 the problems and solutions encountered by occupational health-nursing practitioners in the treatment of an HIVpositive person in an ethical manner, was explored and debated during a workshop. The ethical standards, as described as a result of phase 1, were used as base line for the debate. The problems and possible solutions for each ethical standard were debated.

- During Stage 2 the problems and solutions of the HIV-positive people in the workplace were explored and described by means of semi-structured personal interviews (Burns $\&$ Grove, 1993:365). The central questions to the respondents were formulated with regard to each of the five ethical standards from phase 1 .

\section{Population and sampling and ethical considerations}

The occupational health-nursing practitioners as well as the HIV-positive people were selected purposively (Burns \& Grove, 1993:246). In order for the occupational health-nursing practitioners to be selected, they had to comply with the following sampling criteria:

- They had to be fluent in English and had to be employed as an occupational healthnursing practitioner by the packaging company for at least one year.

- They had to be registered with the South African Nursing Council in General Nursing Science and Occupational Health-nursing.

- They had to be in possession of a Certificate in the counselling of HIV-positive people and had to be involved with the handling of HIV-positive people in the workplace.

Eighteen $(n=18)$ occupational health nurses that met these criteria were included in the workshop.

The HIV-positive people had to comply with the following sampling criteria:

- They had to be fluent in English and employed full time at one of the factories of the packaging company.

- They had to be between 18 and 60 years old and be HIV-positive.

- They had to be treated and counselled by the occupational health-nursing practitioner at that particular factory.

The occupational health nurses were used to contact the HIV-positive person and to get informed consent before the researcher interviewed the person. Interviews were conducted with seven $(\mathrm{n}=7) \mathrm{HIV}$ positive employees.

The researcher adhered to the standards for nurse researchers as described by Denosa (1997).

\section{Data analysis}

The data of phase 2 stage 2 was tape-recorded and transcribed. For phase 2 stage 1 the data was recorded as notes from the workshop. For both stages the methods of reduction, display, conclusion and verification as described by Miles and Huberman (1994:21) were used in the analysis of the data. The data of the two stages were analysed separately. Data was reduced and condensed by organising the data into two main categories, namely problems and solutions. The following sub-categories were employed to display the conclusions:

- Problems/solutions influencing the individual system.

- Problems/solutions influencing the organisational system.

- Problems/solution influencing the health system.

- Problems/solutions influencing the family system.

\section{Trustworthiness}

The measures of Lincoln and Guba (1985:290-300) were used to ensure the trustworthiness of the 
research. The following measures were employed:

- the concept of saturation was employed during data analysis,

- triangulation of data resources in stages one and two;

- $\quad$ peer group debriefing during data analysis; and prolonged engagement.

\section{CONCEPTUAL FRAMEWORK}

During the conceptual phase or Phase I of the research, the ethical-legal framework was described and the concepts defined, in order to formulate the standards for the ethical handling of the HIV-positive person in the workplace. The conceptual framework constitutes the legal norms and ethical standards required to be operationalised during the interaction between the HIV-positive person, the occupational health-nursing practitioner and the employer (Refer to Table 1).

Table 1: Legal-ethical framework for the formulation of the ethical standards

\begin{tabular}{|c|c|}
\hline \multicolumn{2}{|c|}{ LEGAL-ETHICAL FRAMEWORK } \\
\hline 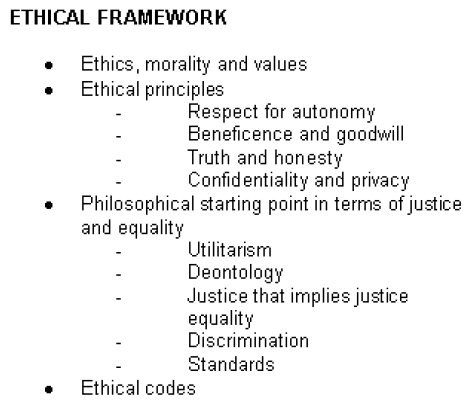 & $\begin{array}{l}\text { LEGAL FRAmEwoRK } \\
\text { - The Constitution (No } 108 \text { of 1996) } \\
\text { - The Labour Relations Act (No EG of 1995) } \\
\text { - The Occupational Health and Safety Act ('No } \\
\text { 181 of 1993) } \\
\text { - The Basic Conditions of Employment Act } \\
\text { (No } 75 \text { of 1997) } \\
\text { - The Compensation for Occupational Injuries } \\
\text { and Diseases Act (No } 130 \text { of } 1993) \\
\text { - The Employment Equity Act (No } 55 \text { of 1998) } \\
\text { - The Nursing Act (No } 50 \text { of 1978) }\end{array}$ \\
\hline
\end{tabular}

The following ethical standards were formulated from the conceptual framework for implementation during the empirical phase or Phase 2 of the research:

The HIV-positive person in the workplace is entitled to fair and equal treatment.

- The autonomy of the HIV-positive person in the workplace must be respected.

- The principles of confidentiality and privacy must be maintained in dealing with the HIVpositive person in the workplace.

- The principles of honesty and truth must be maintained during the interaction with the HIV-positive person in the workplace.

- Maintaining the principles of beneficence (no harm).

\section{RESULTS AND conclusions}

The data collected from the occupational healthnursing practitioners during Stage 1 of Phase 2 was triangulated with the data collected from the HIVpositive people during Stage 2 Phase 2 . The solutions identified by the respondents were used as criteria for setting guidelines for the operationalisation of the ethical standards. The categorisation and interpretation of the two sets of data took place within the conceptual framework (Refer to Table 1).

Guidelines and criteria for the operationalisation of the ethical standards for the occupational healthnursing practitioner in the workplace were formulated. This was achieved by firstly exploring and describing the literature with specific reference to the legal-ethical framework for the occupational health context regarding the interaction with the HIVpositive person at the workplace, in order to formulate ethical standards. Secondly the problems and solutions determined by the two target groups, namely the HIV-positive people and the occupational health-nursing practitioners, were explored and described. The guidelines formulated for each of the ethical standards was obtained from the problems and solutions identified by the two target groups.

The Ethical Standards were made operational by writing guidelines and criteria for every standard. The guidelines and criteria can be used in practice by the occupational health-nursing practitioner for self-evaluation to determine whether or not he/she treats the HIV-positive person in the workplace in an ethical way (Refer to Table 2).

\section{RECOMMENDATIONS}

From the research it is evident that there are many aspects regarding the practical application of ethical standards that require further investigation. The following are examples of such aspects:

\section{Recommendations for further research}

Further research can be undertaken to determine the way in which ethical decision- 
Table 2: Operational Guidelines of the ethical standards 
making influence interaction between the occupational health-nursing practitioner and the HIV-positive person in the workplace. Research by psychiatric nurses could be conducted to determine the way in which the psychiatric support of the HIV-positive person could contribute to the easier acceptance of the diagnosis, as well as achieving and maintaining the maximum level of health.

The self-evaluation guidelines described in 
this document can, through further research, be developed as a complete instrument of which the construct validity, quality and reliability can be tested.

Further research can be conducted to determine the way in which counselling can address the needs of the HIV-positive person.

- Recommendations for the improvement of the occupational health practice and education

It is strongly recommended that counselling skills become the central focus of the curriculum for occupational health-nursing students. This should be a requirement for any nursing student undertaking further study in any field requiring interaction with patients. It is also a prerequisite that nurses develop and become educated in order to be culture-sensitive, particularly in a country like South Africa with its diverse cultures. This is especially required if they want to demonstrate care and quality in nursing.

It is of utmost importance that nurses be educated to be sensitive to and respect the rights of other people. Guidance of nurses in developing judgement skills in order to facilitate ethical decision-making is strongly recommended, as ethical practice is the responsibility of all nurses.

\section{REFERENCES}

ARENDSE, N 1988: HIV and AIDS infected employees: Some legal implications for the work place. Industrial Law Journal, 6(1), Jan. 1989:218-227.

BURNS, N \& GROVE, SK 1993: The practise of Nursing Research - conduct, critique \& utilisation; second edition. Philadelphia: WB Saunders.

DELOUGHERY, GL 1995: Issues and trends in nursing. St Louis: Mosby.

DENOSA, 1997: Ethical standards for nurse researchers.

Denosa: Pretoria.
LINCOLN, YS \& GUBA, EG 1985: Naturalistic inquiry. Sage: London.

MILES, \& HUBERMAN 1994: Qualitative data analysis: A sourcebook of new methods. Beverly Hills CA: Sage.

ODENDAL, FF \& SCHOONEES, PC 1991: HAT: Verklarende woordeboek van die Afrikaanse taal; tweede uitgawe. Perskor: Johannesburg.

PERA SA \& VAN TONDER, S 1996: Etiek in die Verpleegpraktyk. Cape Town: Juta.

PILOT, DF \& HUNGLER, BP 1997: Nursing research principle and methods; fourth edition. London: Oxford University Press.

SCOUB, BD 1994: AIDS \& HIV in perspective: A guide to understanding the virus and its consequences. Cambridge: University Press.

SUID-AFRIKAANSE INSTITUUT VIR RASSEAANGELEENTHEDE 1996: Verbod op die segregasie van MIV-positiewe gevangenes. Pretoria.

SUID-AFRIKAANSE RAAD OP VERPLEGING 1991: Regulasie No R 2598 soos gewysig. Regulasies betreffende die bestek van praktyk van persone wat kragtens die Wet op Verpleging, 1978 Pretoria.

SOUTH AFRICA (Republic) 1993: The Compensation for Occupational Injuries and Diseases Act (No 130 of 1993). 6 October 1993. Government Gazette: Pretoria.

SOUTH AFRICA (Republic) 1993: The Occupational Health and Safety Act (No 181 of 1993). 29 December 1993. Government Gazette: Pretoria.

SOUTH AFRICA (Republic) 1995: The Labour Relations Act (No 66 of 1995). 13 December 1995. Government 
Gazette: Pretoria.

SOUTH AFRICA (Republic) 1996: The Constitution of the Republic of South Africa (Act 108 of 1996). 18

December 1996. Government Gazette: Pretoria.

SOUTH AFRICA (Republic) 1997: The Basic Conditions

of Employment Act (No 75 of 1997). 5 December 1997.

Government Gazette: Pretoria.

SOUTH AFRICA (Republic) 1998: The Employment Equity Act (No 55 of 1998). 19 October 1998.

Government Gazette: Pretoria.

WORLD HEALTH ORGANISATION (WHO) 2000:

Facts sheets on HIV/AIDS: A desktop reference:

Department of Health: Pretoria. 